\title{
EFFECTS OF HABITAT ON CLUTCH SIZE OF ORNATE TREE LIZARDS, UROSAURUS ORNATUS
}

\author{
Gregory Haenel ${ }^{1}$
}

\begin{abstract}
Clutch size is an important determinant of female reproductive success in reptiles. Although female body size explains much variation in clutch size, other important factors include differences in food availability, predation risk, morphology, and demography. Ornate tree lizards, Urosaurus ornatus, display extensive variation in life history traits, including clutch size. Tree lizards primarily use 2 distinct habitat types — trees and rock surfaces—which influence both the performance and morphology of this species and may affect life history traits such as clutch size. As food availability, microclimate, and, potentially, predator escape probabilities differ between these 2 habitats, I predicted that tree- and rockdwelling lizards would allocate resources toward clutch size differently. Clutch size variation was compared among 15 populations of $U$. ornatus sampled from the different habitat types. Urosaurus ornatus individuals living on trees had significantly larger clutches than those living on rocks, even after including the effects of body size and environment. Two potential mechanisms leading to larger clutches in tree-dwelling lizards are (1) differences in food availability and (2) differences in performance (sprint vs. endurance) requirements for predator escape in the 2 habitats. Inconsistent distribution of habitat type across the phylogenetic tree indicates either many cases of independent evolution in the allocation strategies of these lizards or a consistent phenotypically plastic response to similar environmental challenges in different populations.
\end{abstract}

RESumen.-El tamaño de puesta es un determinante importante del éxito reproductivo de las hembras. Aunque el tamaño corporal de la hembra explica gran parte de la variación en el tamaño de puesta de los reptiles, otros factores importantes incluyen las diferencias en la disponibilidad de alimento, el riesgo de depredación, la morfología y la demografía. La lagartija arbolera Urosaurus ornatus exhibe gran variación en características de historia de vida, incluyendo el tamaño de puesta. Esta lagartija usa principalmente dos hábitats distintos, árboles y superficies de rocas, los cuales influyen tanto en el desempeño como en la morfología de esta especie y pueden afectar las características de historia de vida como el tamaño de puesta. En vista de que la disponibilidad de alimento, el microclima y posiblemente el escape de los depredadores difieren entre estos dos hábitats, fue posible predecir que las lagartijas que viven en árboles distribuirían sus recursos de una manera diferente a la de las lagartijas que viven en las rocas con respecto al tamaño de puesta. Comparamos la variación en el tamaño de puesta entre 15 poblaciones de U. ornatus provenientes de los dos tipos de hábitat. Las Urosaurus ornatus que viven en los árboles tuvieron puestas considerablemente más grandes que las que viven en las rocas, aun después de incluir los efectos del tamaño corporal y del ambiente. Dos mecanismos que podrían llevar a puestas más grandes en lagartijas que viven en árboles son (1) diferencias en la disponibilidad de alimento, y (2) diferencias en las capacidades necesarias (velocidad/ resistencia) para eludir depredadores en los dos hábitats. La distribución del tipo de hábitat en el árbol filogenético indica, o muchos casos de evolución independiente en las estrategias de asignación de recursos de estas lagartijas, o una reacción sistemática y fenotípicamente plástica a presiones ambientales similares en distintas poblaciones.

Clutch size is an important reproductive character that directly affects both an individual's evolutionary fitness and the growth rate of a population. However, reproduction involves trade-offs with other important and nonindependent variables, such as growth and age at maturity. Operation of these trade-offs leads to high variation in clutch size, both within and among species. Causes of variation in lizard clutch size include body size (abdominal space in lizards; Shine 1992, Du et al. 2005), prey availability (James and Whitford 1994), egg size (Sinervo et al. 1992), and time in the breeding season (Ballinger 1977, Van Loben Sels and Vitt 1984). In addition, important selective forces may be imposed by habitat (Vitt 1981), either through selection on morphology and performance, as seen in some members of the skink subfamily Lygosomine (flattened body shape; Goodman et al. 2009), or through other ecological processes. Understanding how these mechanisms shape clutch size variation is important for building a working model of life history evolution.

Lizards are excellent model organisms for ecomorphology and life history studies and show evolutionary responses to living on different substrates. For example, rock surfaces can have strong functional and ecological effects on lizards relative to other habitats (Revell et al. 2007,

1 Elon University, CB 2625, Elon, NC 27244. E-mail: haenel@elon.edu 
Goodman et al. 2008, 2009). Recent studies have also made links between morphology and performance in different habitats (Miles 1994, Goodman et al. 2008). However, few have examined how these differences impact reproductive characters in reptiles (Pizzatto et al. 2007, Goodman et al. 2009). As selection acts on the whole organism, strong selection on morphology in a given habitat may lead to trade-offs in life history allocation strategies, including clutch size differences (Pizzatto et al. 2007). If females maximize allocation of energy to egg number, then females with larger body sizes and better body condition should have larger clutches (Shine 1988). The impact of habitat structure on resource acquisition and predation environments may thus result in clutch size differences among populations inhabiting different substrates.

Ornate tree lizards, Urosaurus ornatus, occupy 2 main structural habitats: trees (arboreal) or rocky outcrops and canyons (saxicolous; Miles 1994, Herrel et al. 2001). Proximal responses of $U$. ornatus to contrasting environmental pressures found across its range (Ballinger 1977) and the dramatic differences between living on a rock face and living in trees could partially explain both the variable life histories and the ability of tree lizards to occupy a broad range of environments.

Urosaurus ornatus living in arboreal habitats should find a great range of microclimatesfrom full shade (side of trunk) to open sun (top of canopy) — at any given time, as well as a high relative humidity under the canopy compared to the open canyon walls. Greater insect abundance would be expected among the leaves and branches of trees (a direct site of primary productivity) than on smooth, open rock surfaces. Urosaurus ornatus have cryptic coloration on tree bark, and many potential refugia from predators exist on trees. For example, it is possible for lizards to hide under tree bark or on the opposite sides of branches. Therefore, I predicted that $U$. ornatus living in arboreal (and structurally more complex) habitats should allocate greater resources to reproduction than saxicolous lizards. Optimality models (Smith and Fretwell 1974) predict that when selection acts to optimize offspring size, variation in total reproductive investment will be expressed primarily through changes in offspring number (Wilkinson and Gibbons 2005); thus, having larger clutches is a likely response.
To test the above predictions in $U$. ornatus, I first quantified the relationship of female body size and clutch size and then removed the effects of female body size from clutch size using regression. The potential confounding influence of phylogeny on both female body size and relative clutch size variation was tested for. I then compared a suite of key environmental variables (elevation, latitude, annual temperature, and rainfall) for their effects on body size and relative clutch size variation. I next estimated the effect of habitat type (arboreal and saxicolous) on variation in body size and relative clutch size, while controlling for environmental variation among populations.

One scenario that generates evolutionary divergence leading to speciation is having isolated populations of a single species (i.e., populations that have a common genetic history but presently have limited gene flow) that are exposed to different environmental challenges. The comparison of such populations has high potential for elucidating mechanisms of evolutionary change. In contrast, comparative studies done at or above the species level include genetically distinct and already well-diverged groups that have entire suites of coevolved differences (Herrel et al. 2001), the complexity of which potentially obscures the origin of evolutionary change for any particular character.

\section{Methods}

Urosaurus ornatus is a small xeric-adapted, insectivorous lizard in the family Phrynosomatidae. During May, June, July, and August of 1989-1992, populations were sampled from across their range in the southwestern United States for studies of genetic and geographic variation (Haenel 1997, 2007). Lizards were captured by handheld noose. Substrate use was noted at time of capture, with lizards found on either saxicolous (defined here as rock surfaces ranging from open cliff faces to large, smoothsurfaced boulders) or arboreal (tree) substrates. The rock-dwelling lizards were observed at sites without shade and often were not located near potential refugia. On the other hand, the arboreal habitat was highly shaded and had many refugia close by, such as loose bark or deep cracks in the bark. One population (AN) was observed on fence posts in an open area of low-lying, small rocks within tall grass, very unlike the smooth, exposed rock surfaces used by other saxicolous populations. This unusual 
situation was more similar to the conditions observed for the tree-dwelling lizards, with close association of vegetation and relatively short escape distances, so I classified this population as arboreal. To ensure that sampling timing for each habitat type was not biased toward a particular part of the season, populations were classified by habitat type, ranked by date of sampling, and compared with a Wilcoxon rank test. A significant test statistic would indicate that one of the habitats was sampled more during the same time frame (for example, early or late in the reproductive season) and was thus more likely to contain more of either first or second clutches.

Lizards were weighed using a spring balance $( \pm 0.05 \mathrm{~g})$ and measured for snout-to-vent length (SVL) using a plastic ruler $( \pm 0.5 \mathrm{~mm})$. Clutch size was measured in dissected specimens as number of vitellogenic follicles or oviductal eggs. Table 1 provides detailed information about population location, sample size, and voucher deposition. Further details of specific collecting localities were reported in Table 2 of Haenel (2007). Data on clutch size and female SVL were available from published studies of an additional 6 populations of $U$. ornatus (Table 1). As pooled data were presented in these 6 studies, population means for clutch size and female SVL were used. Size differences between populations were tested using ANOVA in 15 of the populations (individual size data not available for the EP population).

Constraints on sampling did not allow measurement of clutch frequency or relative clutch mass $(\mathrm{RCM})$ in the 10 populations sampled directly in this study, though these are important components of life history variation (Dunham 1982). Therefore, the current study is limited to clutch size variation and does not include overall reproductive output.

Many variables other than substrate may affect clutch size, including female body size, phylogenetic history, rainfall, elevation, latitude, and environmental temperature. Covariation of clutch size with female body size is well documented for lizards (Dunham et al. 1988). Body size covariation was accounted for by using the residuals from a regression of clutch size on female body size. Residuals (providing bodysize-independent measures of clutch size) were then used as the dependent variable in all analyses of clutch size. Trait values were logtransformed.
Individuals that are more closely related may have more-similar (nonindependent) trait values due to recent shared evolutionary history. To test for phylogenetic effects on body size and clutch size, I developed a phylogenetic hypothesis for the 16 populations with the traits and used an approach from a broader phylogeographic study that included these populations (Haenel 2007). In brief, Bayesian analyses of cytochrome $b$ sequences (311 base pairs from one individual sampled from each population; Genbank accession numbers: EU021124, EU021134, EU021138, EU021144, EU021150, EU021152, EU021173, EU021176, EU021178, EU021182, EU021186, EU021189, EU021191, EU021194, EU021197, EU021201) were performed using the program MrBayes (version 3.1; Ronquist and Huelsenbeck 2005) with the Hasegawa, Kishino, and Yano (HKY) model of evolution to generate a phylogenetic hypothesis. The nucleotide evolution model was determined by applying the program ModelTest (version 3.04; Posada and Crandall $1998)$ to the sequence data. Parameter space was explored using 2 metropolis-coupled Markov chain Monte Carlo simulations with 4 incrementally heated chains for $1 \times 10^{6}$ generations. Markov chains were sampled every 100 generations. A plot of generation time versus log-likelihood values showed that stationarity was reached after approximately $3 \times 10^{5}$ generations. Convergence between runs was shown by similarity of mean log-likelihood values. A 50\% majority-rule consensus tree was formed from the equilibrium samples remaining after the burn-in samples were discarded.

The resulting tree was compared qualitatively to the tree structure found in the more complete analysis of 36 tree lizard populations (Haenel 2007). Significant correlation of life history trait values with the phylogenetic structure developed here was tested for with the program PITEST (Abouheif 1999) using 1000 randomizations. If significant phylogenetic signal was found, independent contrasts could be calculated and used in subsequent analyses to control for the phylogenetic effects. If significant phylogenetic signal was not found, each population sample could be treated as an evolutionary independent in subsequent statistical tests. Because latitude and elevation both play a role in determining local climate, they were tested as potential factors affecting female SVL and relative clutch size. Latitude and elevation were taken from Bureau of Land Management or 


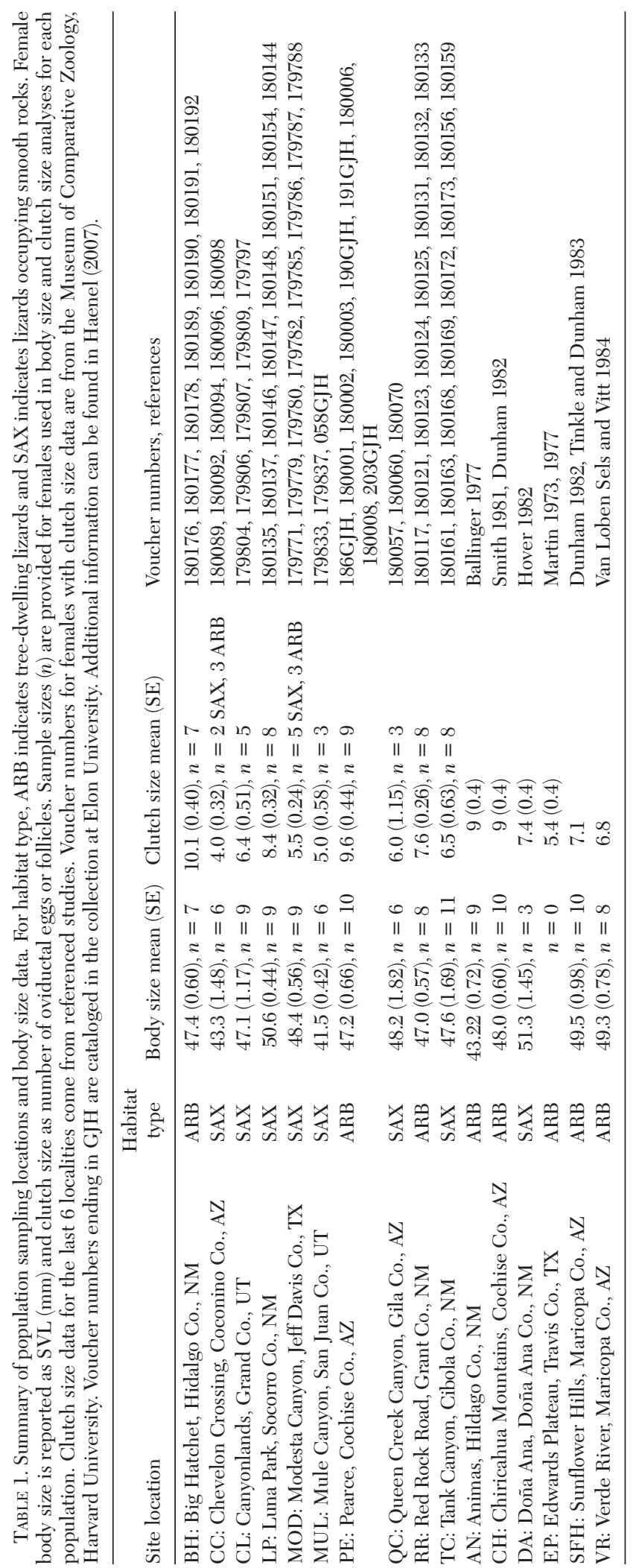


USGS maps. Activity time was assumed to be strongly correlated with mean annual temperature at each locality (Adolph and Porter 1993). Mean annual temperature was estimated from monthly averages for 10 years prior to population sampling (6 locations had only 3-8 years of complete data) taken at the nearest weather station (National Climatic Data Center; http:// wf.ncdc.noaa.gov/oa/ncdc.html). Weather stations were chosen for their proximity and similarity in elevation to population localities. Insect abundance in arid regions tends to be proportional to rainfall (Dunham 1978). Therefore, differences in relative food levels should be comparable to annual differences in rainfall among population localities. Annual rainfall was averaged over the 10 years prior to time of sampling and for each sampling year from data taken at the nearest weather stations (see above). Annual vaules as opposed to activity season values were used because of the strong effects that winter rainfall can have on summer primary productivity in these regions.

As these abiotic factors are highly correlated and thus collinear, principle component analysis (PCA) was conducted to reduce the number of axes needed to explain sample variation in the original measurements. A covariance matrix was used in the PCA analysis, and the number of principle components included in subsequent analyses was determined by examining scree plots. Covariation of substrate type with environmental variation as described by the PCA was explored further with $t$ tests. To control for differences in environments, significant principle components were included as covariates in ANCOVA when the effect of substrate on clutch size was tested. Population means were used for these analyses.

Because substrate use was mixed in 2 populations (see Table 1) and clutch size variation was large even within each population, the ANCOVA was repeated using individual scores of clutch size instead of population averages. While this method included some pseudoreplication of data within populations, it allowed within-population variation in substrate use to be included, which better reflected more of the variability among individuals. This test did not include published population data. Only data from individuals found on the most commonly used substrate type in the 2 mixed populations were included for all other analyses.
Statistical tests were carried out in SAS (SAS/ STAT 1985) unless otherwise noted. Variables were log-transformed as needed to meet the assumptions of statistical tests. If assumptions of parametric tests could not be met, nonparametric tests were used.

\section{REsults}

First, female body size, as estimated by SVL, was compared across populations; then, the effect of female SVL on clutch size was examined. Snout-to-vent length of females differed significantly among the 10 populations based on the 64 gravid females directly sampled in this study (ANOVA: $F_{9,54}=6.07 ; P<0.001$ ). Clutch size was significantly related to female SVL in the pooled sample of 64 females with eggs from all populations directly sampled in this study (Pearson correlation: $r=0.31, P<0.01)$. Residual clutch size (variation in clutch size remaining after regression of clutch size on female SVL) varied significantly among populations $\left(F_{9,54}=\right.$ 22.05, $P<0.001)$ indicating that there was significant variation in clutch size among populations after the effect of female body size was removed from the analysis. These body sizeindependent (i.e., female SVL-independent) estimates of clutch size were then used as the dependent variables in the analyses below. Also, because clutch size in $U$. ornatus tends to decrease through the season (Martin 1977), the effect of sample timing in each habitat type was tested, and results were not significant (no effect detected; Wilcoxon rank test: $P=0.589$; month, $P=0.329$; year, $P=0.859)$.

The majority-rule consensus Bayesian trees for both runs were identical and well-supported (Fig. 1). Relative position of populations on this phylogeny was very similar to the more fully sampled phylogenetic hypothesis of 36 populations (see Fig. 2 in Haenel 2007). Female SVL and body size-independent residuals of clutch size, the dependent variable used in ANCOVA, were not significantly related to phylogeny $(P=0.37$ and $P=0.06$, respectively). Habitat type was also not correlated with the phylogeny of these populations (runs test: $P=0.51$ ). Therefore, independent contrasts were not used in subsequent analyses.

The first principle component axis explained approximately $88 \%$ of the variation among sites, and rainfall was the most important variable (component loading $=0.94$; Table 2$)$. Only PC1 


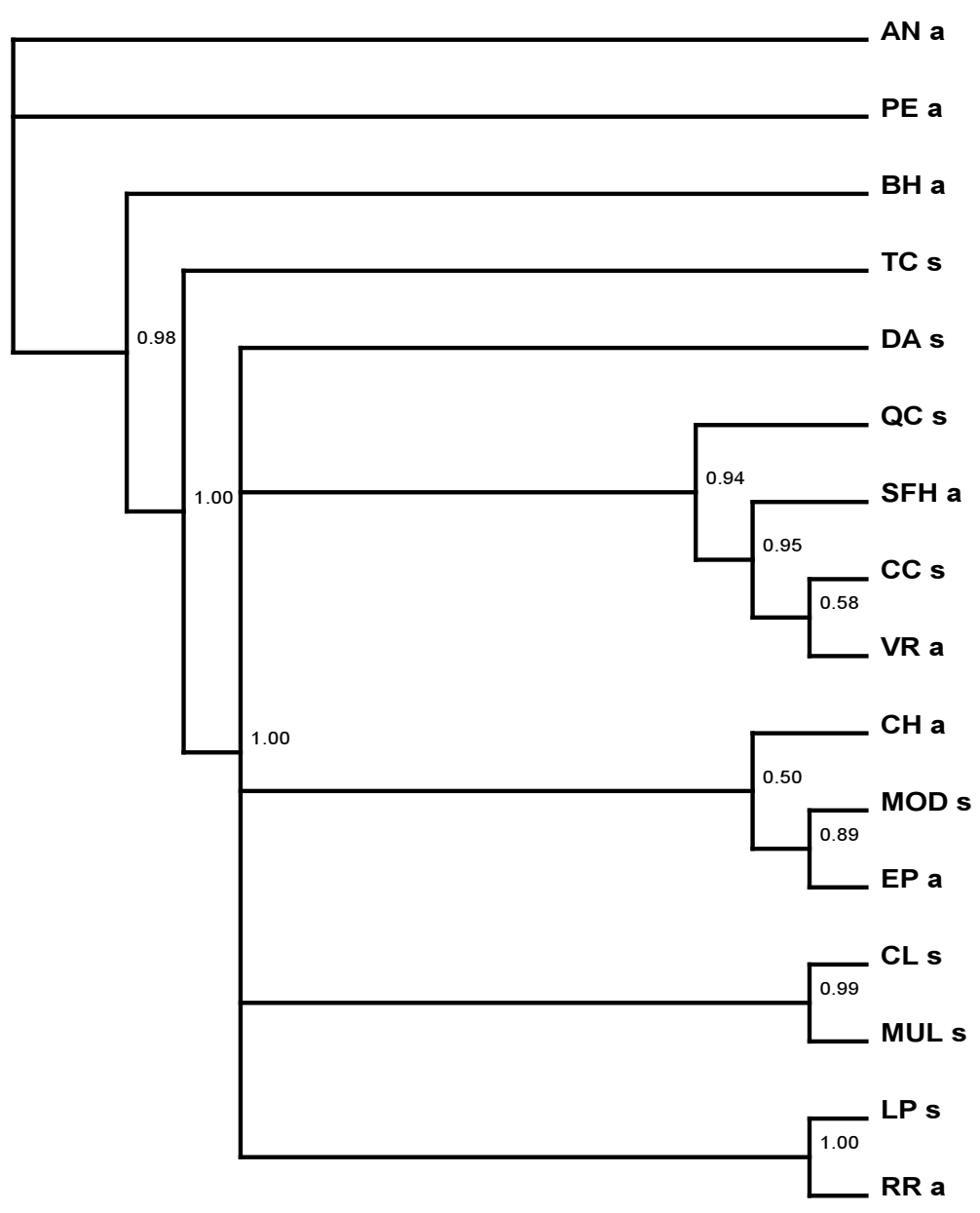

Fig. 1. Consensus cytochrome $b$ sequence tree for 16 populations of $U$. ornatus used in this study. The trees from each run had mean log-likelihood values of -1142.542 and -1134.921 , respectively. Numbers at nodes indicate probability levels of each clade, most of which were very high. Population names are in Table 1 and are followed by habitat type $(\mathrm{a}=$ arboreal and $s=$ saxicolous). This tree was drawn using TreeView version 1.6.6 (Page 1996). The only difference between this tree and the larger analysis of Haenel (2007) is the placement of the $\mathrm{CH}$ population, which also has a low posterior probability $(0.50)$.

TABLE 2. Results of principle components (PC) analysis of environmental variables at 16 Urosaurus ornatus sampling locations. Component loadings are reported for each environmental variable. The bottom row shows the percent variation explained by each principle component axis. Eigenvalues of the covariance matrix were $0.1178,0.0138$, and 0.0019 for PC axes 1-3 respectively.

\begin{tabular}{lccc}
\hline & PC 1 & PC 2 & PC 3 \\
\hline Elevation & 0.2068 & 0.9608 & 0.1844 \\
Latitude & 0.2762 & -0.0679 & -0.0040 \\
Rain & 0.9354 & -0.2065 & 0.0412 \\
Temperature & -0.0769 & -0.1720 & 0.9819 \\
\% Variation & 88.19 & 10.40 & 0.01 \\
\hline
\end{tabular}

was suitable for further analysis based on the scree plot. Comparison of PC1 by the 2 sub- strate types found a significant difference (2tailed $t$ test: $t=-2.36, P=0.033$ ) and the environmental variable with the highest loading (rainfall) was lower in arboreal populations (2-tailed $t$ test: $t=-2.27, P=0.039$ ).

Residual clutch sizes for arboreal females were significantly larger than for females living on smooth rocks when environmental variables were accounted for (using PCl as a covariate in ANCOVA: $\mathrm{R}^{2}=0.19, F_{1,12}=8.50, P=0.012$; homogeneity of regressions test, $P=0.419$ ). From a descriptive perspective, mean clutch size was almost 2 eggs larger on average for arboreal lizards $(\bar{x}=8.2$ eggs, $\mathrm{SE}=0.44)$ than for saxicolous lizards $(\bar{x}=6.4$ eggs, $\mathrm{SE}=0.28$; $t$ test: 


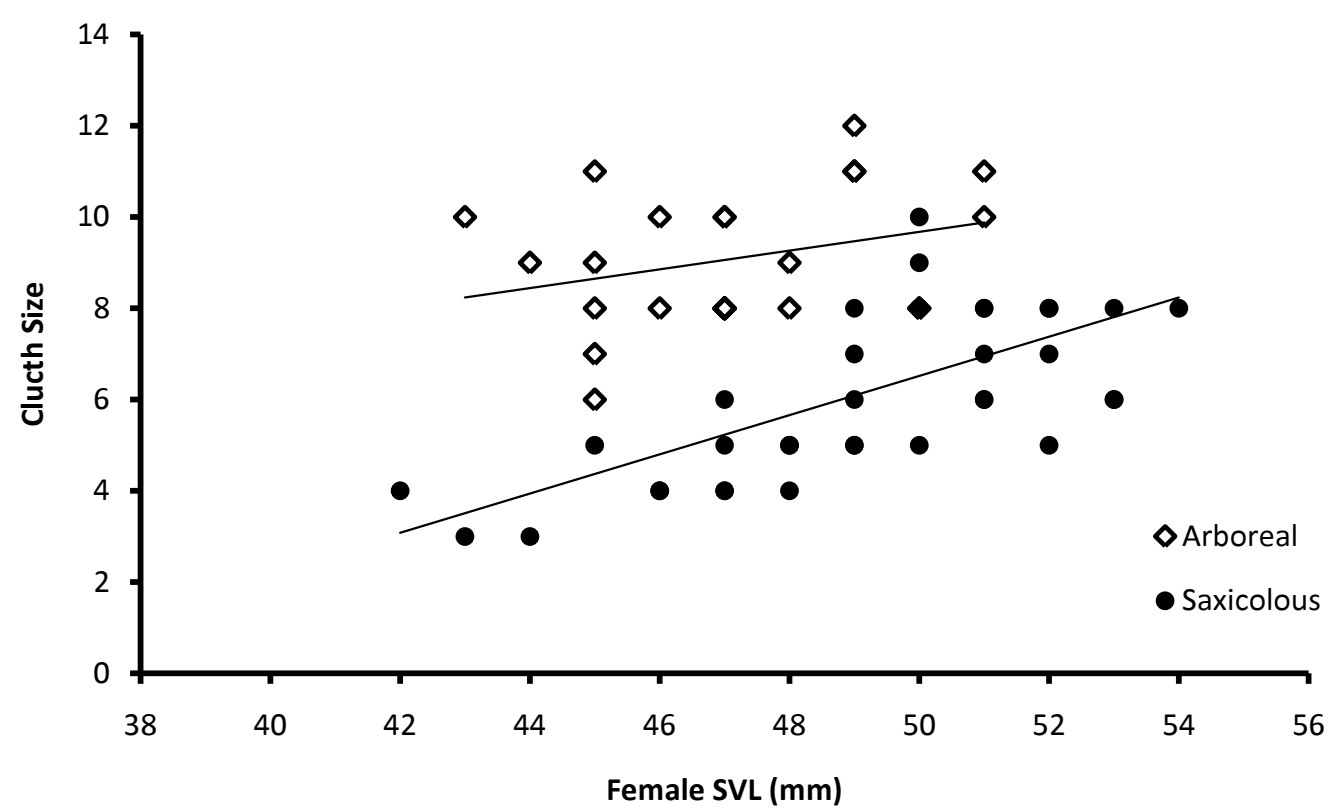

Fig. 2. Relationship of clutch size to female body size for sampled individuals. Arboreal lizards are indicated by open diamonds, and those living on rocks are indicated by closed circles. Best-fit lines for these nontransformed data illustrate the relationship for each substrate type. Population level analyses are presented in the text.

$t=8.60, \mathrm{df}=62, P<0.001)$. Individual clutch size residuals were also significantly related to substrate (using $\mathrm{PCl}$ as a covariate in ANCOVA: $\mathrm{R}^{2}=0.55, F_{1,61}=24.60, P<0.001$; homogeneity of regressions test: $P=0.603)$. Figure 2 shows the relationship of clutch size and female SVL by substrate type using individual values.

Female SVL was not significantly affected by substrate type when environmental differences were accounted for (using PCl as a covariate in ANCOVA: $F_{1,12}=1.32, P=0.302$; homogeneity of regressions test: $P=0.255$ ).

\section{DisCussion}

Clutch size is a key component of female reproductive success, and in this study the habitat a lizard lived in significantly influenced relative clutch sizes. Tree-dwelling $U$. ornatus had larger clutches than similarly sized rockdwelling individuals, though body size tended to overlap between the 2 habitat types. This result has important implications for relative fitness of females in the different habitats, life history traits that covary with clutch size, and population growth in this broadly distributed lizard. Although body size was statistically controlled, habitat may also affect body shape and thus clutch size. Differences in biophysical environments, food availability, and sprint performance in these 2 habitats may underlie clutch size differences.

The correlation of female body size and clutch size is well known in ectotherms, and body size, along with shape and volume, plays an important role in reproductive output of females (Shine 1992, Du et al. 2005, Goodman et al. 2009). Evolutionary changes in body volume may not actually change clutch mass (Goodman et al. 2009), indicating that the correlation of clutch size and body size may represent optimal clutch size rather than maximal clutch size (Du et al. 2005). As habitat type also influences the shape of U. ornatus (Miles 1994, Herrel et al. 2001), habitat could be a pathway through which clutch size is modified in these lizards. Rock- and cliff-dwelling populations of $U$. ornatus were characterized by flatter bodies than tree-dwelling populations (Herrel et al. 2001). Rockdwelling skinks also showed relatively flattened body forms (Goodman et al. 2009). Interestingly, no difference was found in reproductive output between the flatter skinks and the more rounded ones. If this pattern also occurs in $U$. ornatus, morphological differences of females living on rocks and trees would not be a major 
cause of differences in relative clutch size reported here.

Two additional general processes may be driving clutch size differences observed across the 2 habitats. The first is a presumably more favorable microhabitat provided by trees in this hot, arid region. Living in "tree microhabitat" may reduce the energetic costs of thermoregulation and foraging, which could allow for greater activity time, greater energy intake and more efficient energy-processing. The second, and nonexclusive, mechanism is better crypsis and differing ability to escape predators on trees and exposed rock surfaces. Both of these processes remain untested at present, and their implications are explored below.

Mechanisms underlying how tree microhabitat drives increased clutch size may include (1) higher thermoregulatory costs associated with living on exposed rock surfaces and (2) greater insect abundance and food availability in trees relative to rock surfaces. Comparisons of the thermal profiles of habitats of $U$. ornatus and $U$. graciosus, a sister taxon that lives in hotter, more exposed habitats, showed that $U$. ornatus had greater access to thermal refugia provided by crevices in large mesquite trees and loose bark, thereby allowing it to maintain a lower body temperature (Vitt et al. 1981). Water flux rates and afternoon body temperatures were also lower in $U$. ornatus, which utilized the closed canopy of large mesquite trees at the central Arizona study site (Congdon et al. 1982). Urosaurus ornatus may actively avoid thermally extreme environments and would potentially find exposed rock surfaces restrictive to total available activity time.

Many desert lizards, including U. ornatus, vary clutch size in response to proximal variation in resources (Ballinger 1977). Rainfall was the most important environmental variable describing differences among populations along the first principle component axis in the populations studied here. Arboreal populations tended to be in areas with lower rainfall, but these populations were often found in trees along washes and rivers (many only flowing during part of the year), where there is potentially greater water availability from runoff collection and pools. In contrast, many of the sampled saxicolous populations occurred in areas with few or only very small trees. These areas did not provide an arboreal option. If food resource levels are correlated with rainfall, higher food abundance would not be expected in the areas sampled where lizards tend to live in trees. However, differences in local habitat structure may override the influence of annual rainfall differences on food availability. In fact, arthropod abundance was 2-4 times higher in woodland habitats relative to rock slides used by a population of $U$. ornatus in southeastern Arizona (Smith 1996). If this result is general, $U$. ornatus living on trees potentially have access to greater amounts of energy that could be allocated to egg production.

Predator escape may also be important because gravid lizards experience a significant reduction in running performance (Miles et al. 2000, Husak 2006, Cooper et al. 2009). Gravid female collared lizards, Crotaphytus collaris, showed decreased predator escape speeds compared to nongravid females but not a decrease in proportion of maximal performance capacity (Husak 2006). This may be because gravid females also decreased flight distance. In many species of lizards, gravid females show increased use of crypsis for predator escape compared to their use of sprinting when not gravid (Bauwens and Thoen 1981, Cooper et al. 1990). Urosaurus ornatus tends to be more cryptic on tree bark than on smooth rock surfaces (personal observation), potentially reducing the need for gravid females to sprint long distances to escape predators in arboreal habitat. Smaller clutch sizes in rock-dwelling lizards could benefit survivorship of females if larger clutches decrease sprinting abilities. This outcome would be expected if gravid females were slower in proportion to the physical size of their burden (Shine 2003). Endurance and survivorship of female sideblotched lizards, Uta stansburiana, were higher when clutch size was experimentally reduced (Miles et al. 2000). Egg size (not measured in this study, but which may be inversely related to clutch size) also impacted body shape and escape behavior in Uta stansburiana (Lancaster et al. 2010). Populations of $U$. ornatus living on cliffs showed the highest approach distances (relative to other habitats), implying a need for longer escape distances in this habitat (Herrel et al. 2001). While gravid females living on rocks may not be able to escape from predators as easily as those in trees, the effects of being gravid on sprint speed are complex (Olsson et al. 2000), and conflicting results have even been found among populations of a single species (Qualls and Shine 1997). 
Demographic environment, though beyond the scope of my analysis, can have a large effect on the expression of life history traits (Dunham 1982). Populations can reach high densities in open mesquite woodlands, while other populations are equally abundant in rocky canyons that are void of trees (Dunham 1982). Relatively lower clutch sizes may be balanced by increased adult and juvenile survivorship, increased clutch frequency, or earlier reproduction. For example, smaller clutches could be balanced by increased clutch frequency in areas with longer breeding seasons. While the above life history characters are all variable in $U$. ornatus (Ballinger 1977, Dunham 1982), the sampling over a large range of elevations, latitudes, and years in my study indicates an overriding force of habitat in determining clutch size. Substrate type is thus an important variable to consider in the suite of factors shaping the life history of these lizards.

The lack of association between habitats and phylogeny (Fig. 1) indicates that changes in relative clutch size with habitat are most likely parallel processes occurring independently among populations. Whether this variation represents local adaptation through natural selection or phenotypic plasticity depends on the genetic basis for clutch size variation. While selection on clutch size may be occurring (for example, if smaller clutches lead to higher survivorship in rock-dwelling females), lack of a genetic basis for the variation would mean that the variation observed among these lizard populations due to habitat may not be a long-term evolutionary response (Irschick and Meyers 2007). In a similar lizard system, the effects of egg size on escape behavior were mediated through maternal effects but still had an important impact on survivorship (Lancaster et al. 2010).

Urosaurus ornatus populations are able to successfully persist on both trees and rock surfaces; however, smooth rock surfaces may represent a suboptimal habitat type with respect to clutch size. Clutch size is, however, only one necessary character out of a suite of characters that determine lifetime reproductive success. Urosaurus ornatus are highly variable in their expression of most life history traits, including clutch size; and differences in survivorship or clutch frequency could make up the differences found here for instantaneous reproductive output between the 2 habitat types. The plastic life history strategies of $U$. ornatus enable it to maintain viable populations across many environmental conditions and habitats and could help buffer it from extinction as habitats shift through time.

\section{ACKNOWLEDGMENTS}

This work was completed in part with funding of an Elon University Faculty Research and Development Grant. Two anonymous reviewers provided helpful comments on previous drafts of this manuscript. Lizards were collected under permit from the states of Utah, Arizona, Texas, and New Mexico and in compliance with IACUC Protocol \# B-910104 University of Pennsylvania.

\section{Literature Cited}

ABouHEIF, E. 1999. A method for testing the assumption of phylogenetic independence in comparative data. Evolutionary Ecology Research 1:895-909.

ADOLPH, S.C., AND W.P. PORTER. 1993. Temperature, activity, and lizard life histories. American Naturalist 142: 273-295.

BALLINGER, R.E. 1977. Reproductive strategies: food availability as a source of proximal variation in a lizard. Ecology 58:628-635.

Bauwens, D., and C. Thoen. 1981. Escape tactics and vulnerability to predation associated with reproduction in the lizard Lacerta vivipara. Journal of Animal Ecology 50:733-743.

Congdon, J.D., L.J. Vitt, R.C. Van Loben Sels, and R.D. OHMART. 1982. The ecological significance of water flux rates in arboreal desert lizards of the genus Urosaurus. Physiological Zoology 55:317-322.

Cooper, W.E., JR., L.J. VitT, R. Hedges, and R.B. Huey 1990. Locomotor impairment and defense in gravid lizards (Eumeces laticeps): behavioral shift in activity may offset costs of reproduction in an active forager. Behavioral Ecology and Sociobology 27:153-157.

COOPER, W.E., JR., D.S. WiLSON, AND G.R. SMITH. 2009. Sex, reproductive status, and cost of tail autotomy via decreased running speed in lizards. Ethology 115:7-13.

Du, W., X. Ji, AND R. Shine. 2005. Does body volume constrain reproductive output in lizards? Biology Letters 1:98-100.

Dunham, A.E. 1978. Food availability as a proximate factor influencing individual growth rates in the iguanid lizard Sceloporus merriami. Ecology 59: $770-778$.

1982. Demographic and life history variations among populations of the iguanid lizard Urosaurus ornatus: implications for the study of life history phenomena in lizards. Herpetologica 38:208-221.

Dunham, A.E., D.B. Miles, and D.N. Reznick. 1988. Life history patterns in squamate reptiles. Pages 441-522 in C. Gans and R.B. Huey, editors, Biology of the Reptilia. Alan R. Liss, New York, NY.

Goodman, B.A., S.C. Hudson, AND J.L. IsaAc. 2009. The evolution of body shape in response to habitat: is 
reproductive output reduced in flat lizards? Evolution 63:1279-1291.

Goodman, B.A., D.B. Miles, and L. Schwarzkopf. 2008 Life on the rocks: habitat use drives morphological and performance evolution in lizards. Ecology 89: 3462-3471.

Haenel, G.J. 1997. Mitochondrial DNA variation in populations of the tree lizard, Urosaurus ornatus. Copeia 1997:174-178

. 2007. Phylogeography of the tree lizard, Urosaurus ornatus: responses of populations to past climate change. Molecular Ecology 16:4321-4334.

Herrel, A., J.J. Meyers, and B. Vanhooydonck. 2001. Correlations between habitat use and body shape in a phrynosomatid lizard (Urosaurus ornatus): a population-level analysis. Biological Journal of the Linnean Society 74:305-314.

Hover, E.L. 1982. Behavioral correlates of a throat color polymorphism in a lizard. Doctoral dissertation, University of Michigan, Ann Arbor, MI.

HusaK, J.F. 2006. Do female collared lizards change field use of maximal sprint speed capacity when gravid? Oecologia 150:339-343.

IRSCHICK, D.J., AND J.J. MEYERS. 2007. An analysis of the relative roles of plasticity and natural selection in the morphology and performance of a lizard (Urosaurus ornatus). Oecologia 153:489-499.

James, C.D., AND W.G. Whitford. 1994. An experimental study of phenotypic plasticity in the clutch size of a lizard. Oikos 70:49-56.

Lancaster, L.T., A.G. McAdam, and B. Sinervo. 2010. Maternal adjustment of egg size organizes alternative escape behaviors, promoting adaptive phenotypic integration. Evolution 64:1607-1621.

Martin, R.F. 1973. Reproduction in the tree lizard (Urosaurus ornatus) in central Texas: drought conditions. Herpetologica 29:27-32.

1977. Variation in the reproductive productivity of range margin tree lizards (Urosaurus ornatus). Copeia 1977:83-92

Miles, D.B. 1994. Population differentiation in locomotor performance and the potential response of a terrestria organism to global environmental change. American Zoologist 34:422-436.

Miles, D.B., B. Sinervo, and W.A. Frankino. 2000. Reproductive burden, locomotor performance, and the cost of reproduction in free ranging lizards. Evolution 54:1386-1395.

Olsson, M., R. Shine, And E. BaK-Olsson. 2000. Locomotor impairment of gravid lizards: is the burden physical or physiological? Journal of Evolutionary Biology 13:263-268.

PAGE, R.D.M. 1996. TreeView: an application to display phylogenetic trees on personal computers. Computer Applications in the Biosciences 12:357-358.

PizzatTo, L., S.M. Almeida-Santos, And R. Shine. 2007. Life-history adaptations to arboreality in snakes. Ecology 88:359-366.
Posada, D., and K.A. Crandall. 1998. ModelTest: testing the model of DNA substitution. Bioinformatics 14: 817-818.

QuALls, F.J., AND R. SHINE. 1997. Geographic variation in "costs of reproduction" in the scincid lizard Lampropholis guichenoti. Functional Ecology 11:757-763.

Revell, L.J., M.A. Johnson, J.A. Schulte III, J.J. Kolbe, AND J.B. Losos. 2007. A phylogenetic test for adaptive convergence in rock-dwelling lizards. Evolution 61:2898-2912

Ronquist, F., And J. Huelsenbeck. 2005. MrBayes 3: Bayesian phylogenetic inference under mixed models. Bioinformatics Applications Note 19:1572-1574.

SAS/STAT. 1985. Guide for Personal Computers, version 6. SAS Institute, Inc., Cary, NC.

Shine, R. 1988. The evolution of large body size in females: a critique of Darwin's "fecundity advantage" model. American Naturalist 131:124-131.

1992. Relative clutch mass and body shape in lizards and snakes: is reproductive investment constrained or optimized? Evolution 46:828-833.

2003. Effects of pregnancy on locomotor performance: an experimental study on lizards. Oecologia 136:450-456.

Sinervo, B., P. Doughty, R.B. Huey, And K. Zamudio. 1992. Allometric engineering: a causal analysis of natural selection in offspring size. Science 258:1927-1930.

Smith, C.C., And S.D. Fretwell. 1974. The optimal balance between size and number of offspring. American Naturalist 108:499-506.

SмiтH, D.C. 1981. Competitive interactions of the striped plateau lizard (Sceloporus virgatus) and the tree lizard (Urosaurus ornatus). Ecology 62:679-687.

Sмith, G.R. 1996. Habitat use and its effect on body size distribution in a population of the tree lizard, Urosaurus ornatus. Journal of Herpetology 30:530-533.

Tinkle, D.W., And A.E. Dunham. 1983. Demography of the tree lizard, Urosaurus ornatus, in central Arizona. Copeia 1983:585-598.

Van Loben SELS, R.C., AND L.J. VitT. 1984. Desert lizard reproduction: seasonal and annual variation in Urosaurus ornatus (Iguanidae). Canadian Journal of Zoology 62:1779-1787.

VITT, L.J. 1981. Lizard reproduction: habitat specificity and constraints on relative clutch mass. American Naturalist 117:506-514.

Vitt, L.J., R.C. Van Loben Sels, and R.D. Ohmart. 1981. Ecological relationships among arboreal desert lizards. Ecology 62:398-410.

Wilkinson, L.R., AND J.W. GibBons. 2005. Patterns of reproductive allocation: clutch and egg size variation in three freshwater turtles. Copeia 2005:868-879.

Received 17 August 2010 Accepted 15 February 2011 